\title{
Angioedema, endothelium, ACE2, and bradykinin - interrelationships in COVID-19: a case report
}

\author{
Angioedema, Endotélio, ECA2 e bradicinina - inter-relações na COVID-19: \\ um relato de caso
}

Francisco Kleyton Zacarias Florêncio ${ }^{1,2}$ (D), Maiza de Oliveira Tenório ${ }^{3}$ (D), Aluísio Roberto Andrade Macedo Júnior ${ }^{1,2}$ (D), Sandro Gonçalves de Lima ${ }^{1,3,4}$ (D)

\begin{abstract}
COVID-19 is a new disease, whose several atypical clinical manifestations began to be observed with the evolution of the pandemic, and have been investigated to understand the pathophysiology of the disease. In this article, the objective is to describe a case of angioedema in COVID-19, considered an atypical manifestation, and rarely described in the literature. The case is of a 55-year-old patient who sought medical attention for a complaint of intermittent fever for four days. On the seventh day, he manifested angioedema in the left zygomatic projection and the right subpalpebral region. The patient had no history of angioedema earlier in life. The following day, he presented a regression of the angioedema concerning the previous day. After this period, the patient progressed well and became asymptomatic. The RT-PCR laboratory test performed on the first days of manifesting symptoms was positive for SARS-CoV-2. We correlate the onset of angioedema with the possible endotheliitis present in the disease, which has been evidenced by the observation of severe endothelial injury associated with the intracellular presence of the virus in several histopathological studies of patients with COVID-19. Also, possible deregulation of the Kininogen-Kallikrein-Kinin System (KKKS) could explain this manifestation, as SARS-CoV-2 binds to the ACE2 receptor, which is responsible for degrading kinins, such as bradykinin.
\end{abstract}

Keywords: Coronavirus Infections; Pandemics; Angioedema; Endothelium; Bradkynin.

\section{RESUMO}

A COVID-19 é uma doença nova, cujas diversas manifestações clínicas atípicas começaram a ser observadas com a evolução da pandemia e foram investigadas com o objetivo de compreender a fisiopatologia da doença. Neste artigo, o objetivo é descrever um caso de angioedema no COVID-19, considerado manifestação atípica e raramente descrito na literatura. O caso é de um paciente de 55 anos que procurou atendimento médico por uma queixa de febre intermitente há quatro dias. No sétimo dia, manifestou angioedema na projeção zigomática esquerda e na região subpalpebral direita. Não tinha histórico de apresentar angioedema. No dia seguinte, ele apresentou regressão do angioedema em relação ao dia anterior. Após esse período, o paciente progrediu bem e tornou-se assintomático. O teste laboratorial de RT-PCR realizado nos primeiros dias de manifestação dos sintomas foi positivo para SARS-CoV-2. Correlacionamos o início do angioedema com a possível endotelite presente na doença, o que foi evidenciado pela observação de lesão endotelial grave associada à presença intracelular do vírus em vários estudos histopatológicos de pacientes com COVID-19. Além disso, uma possível desregulação do sistema CininogênioCalicreína-Cinina poderia explicar essa manifestação, já que o SARS-CoV-2 se liga ao receptor ACE2, responsável pela degradação de cininas, como a bradicinina.

Palavras-chave: Infecções por Coronavírus; Pandemias; Angioedema; Endotélio; Bradicinina.

1. Hospital das Clínicas da Universidade Federal de Pernambuco (UFPE), Recife (PE), Brasil.

2. Hospital Metropolitano Sul Dom Hélder Câmara, Cabo de Santo Agostinho (PE), Brasil.

3. Centro de Ciências Médicas, UFPE, Recife (PE), Brasil.

4. Departamento de Medicina Clínica, UFPE, Recife (PE), Brasil.

$\triangle$ Maiza de Oliveira Tenório. Rua Guarany, 23 - Cid. Tabajara. CEP: 53350-320. Olinda (PE), Brasil. maizatenorio@hotmail.com | Recebido em: 17/07/2020 | Aprovado em: 19/08/2020 


\section{INTRODUCTION}

COVID-19 (from COronaVIrusDisease-2019) is a new disease, for which studies on its pathophysiology have demonstrated that there is a possible interaction between the endothelium and the immune system. The degree of aggression and the magnitude of the inflammatory response determine how the disease progresses ${ }^{1,2}$, which may explain the variety of clinical manifestations described in the literature.

Rodriguez-Morales et al. reported fever, cough, and dyspnea as the predominant symptoms of COVID-193. Other symptoms include headache, myalgia, conjunctivitis, sore throat, anosmia, nausea, and diarrhea ${ }^{4,5}$. However, other less frequent clinical features of the disease have also been reported, such as atypical skin eruptions ${ }^{6}$. Understanding the possible symptoms of this disease is imperative for identifying suspected cases.

Below, we present the clinical case of a patient who, during COVID-19, presented with angioedema of the face, an atypical symptom, which has rarely been described for this new disease.

\section{CASE REPORT}

A 55-year-old male patient, brown-skinned, married, retired, living in Recife-Pernambuco/Brazil, sought medical care because he was complaining of intermittent fever for four days. He presented no other symptoms at the time of the appointment, although his wife was being monitored for presenting with symptoms of COVID-19 and his daughter works as a hospital nurse. They all live in the same house.

He reported a personal history of non-Hodgkin's lymphoma, for which he had undergone eight chemotherapy sessions and was in remission. There were no reports of kidney disease, stroke (CVA), hypertension, diabetes mellitus (DM), or past bleeding; he was taking no other medication and reported no allergies.

At the first appointment, he was prescribed a $500 \mathrm{mg}$ oral dose of azithromycin once daily for five days, two and a half tablets of $6 \mathrm{mg}$ oral ivermectin in a single dose (weight $75 \mathrm{~kg}$ ), oral acetylsalicylic acid (ASA) $100 \mathrm{mg}$, taking three tablets in the first day and one tablet per day for the following fourteen days, oral atorvastatin $10 \mathrm{mg}$ taken once at night for fifteen days, and supportive measures such as lying in a prone position for two hours three times a day, and using an artisanal PEAP. The patient reported that he began taking the medication the day after the appointment, and continued to be monitored as his disease developed.

On the fifth day of the disease, the patient reported malaise and sweating, but did not present with fever. On the seventh day, however, he presented with vomiting and angioedema in the right and left subpalpebral region and in the left zygomatic projection (Photographs 1 and 2). The angioedema was significant on the left and relatively less significant on the right. The patient had no history of angioedema earlier in life. No medication was prescribed to treat the angioedema; only medical observation was maintained to monitor progression. At the end of the eighth day of the disease, he continued feeling nauseous and vomiting, but the angioedema had regressed concerning the previous day, returning to his normal aspect (Photograph 3 ). During this period, he was prescribed an $8 \mathrm{mg}$ sublingual dose of ondansetron for nausea and vomiting four times per day. During the evolution, the patient reported no erythematous rashes, itching, anosmia, or dyspnea. After this period and with the above-described procedures, the patient evolved well and became asymptomatic, until he was discharged from the follow-up around the $15^{\text {th }}$ day of the disease.

The RT-PCR laboratory test performed on the first days of manifesting symptoms was positive for SARS-CoV-2.

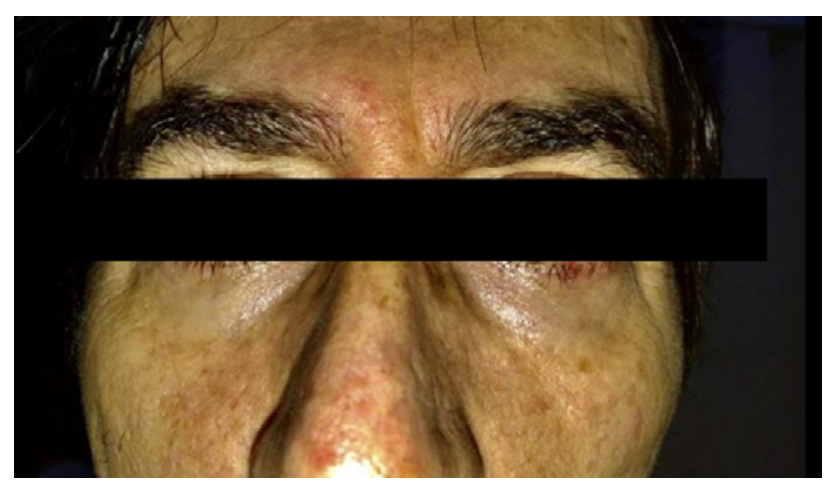

Photograph 1: depicts angioedema in the subpalpebral region and in the left zygomatic projection on the seventh day. 


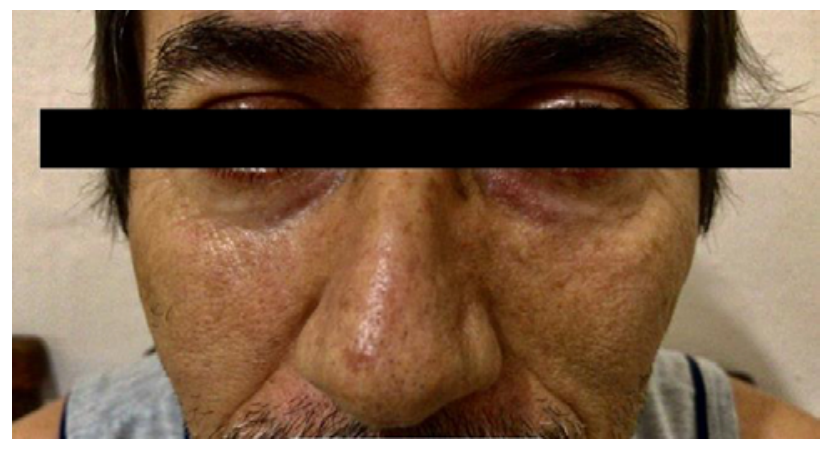

Photograph 2: demonstrates angioedema in both lower subpalpebral regions and in the patient's left zygomatic projection on the seventh day of the disease.

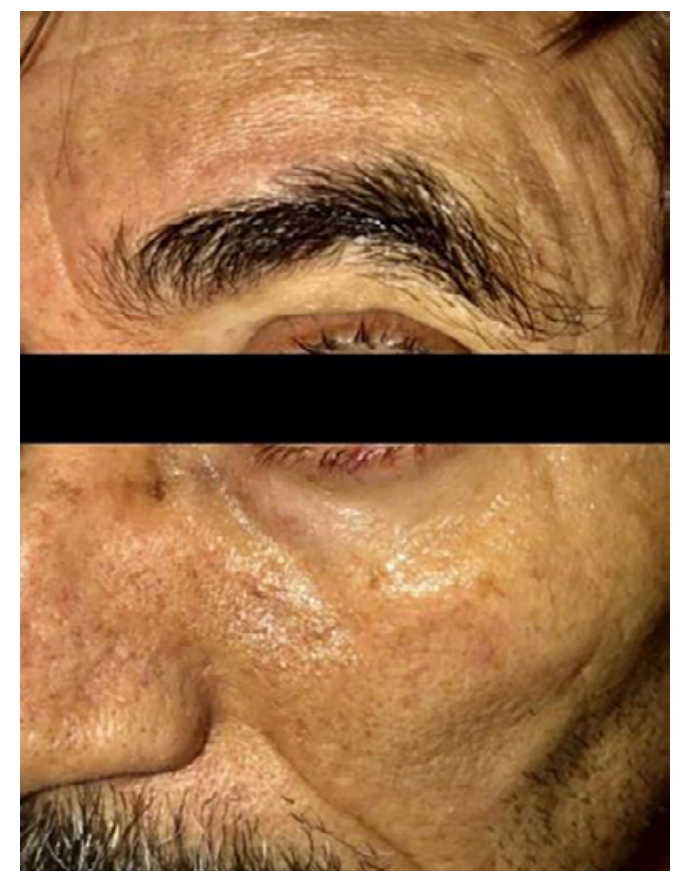

Photograph 3: demonstrates, on the eighth day of the disease, the regression of angioedema that appeared on the seventh day of the patient's COVID-19 in this case report.

\section{DISCUSSION}

Angioedema is characterized by an episode of edema that affects the deep dermis and subcutaneous tissue and may involve regions of the face, lip, neck, and extremities? ${ }^{7}$. Episodes of angioedema in COVID-19 constitute an atypical manifestation, and its description in the literature is rare. Angioedema occurs due to an increase in the permeability of submucosal or subcutaneous capillaries and venules due to the presence of chemical mediators such as prostaglandins, proteases, bradykinin, and histamine ${ }^{7}$.

A case was reported by Cohen et al., in which the patient presented with angioedema on the twelfth day of COVID-19, and was using an ACE inhibitor. The patient in the case described herein, however, had taken no other medication before the medical consultation. The present case and that of Cohen et al. are the only cases in the literature that describe angioedema as a clinical manifestation in COVID-19.

One of the hypotheses raised to explain angioedema in COVID-19 is related to the Kininogen-Kallikrein-Kinin System (KKKS) ${ }^{8}$. In this system, pre-kallikreins released from the liver give rise to plasma and tissue kallikreins, which act on kininogen, resulting in the production of kinins, such as kallidin (or lysyl-bradykinin) and bradykinin (Flowchart 1$)^{9}$.

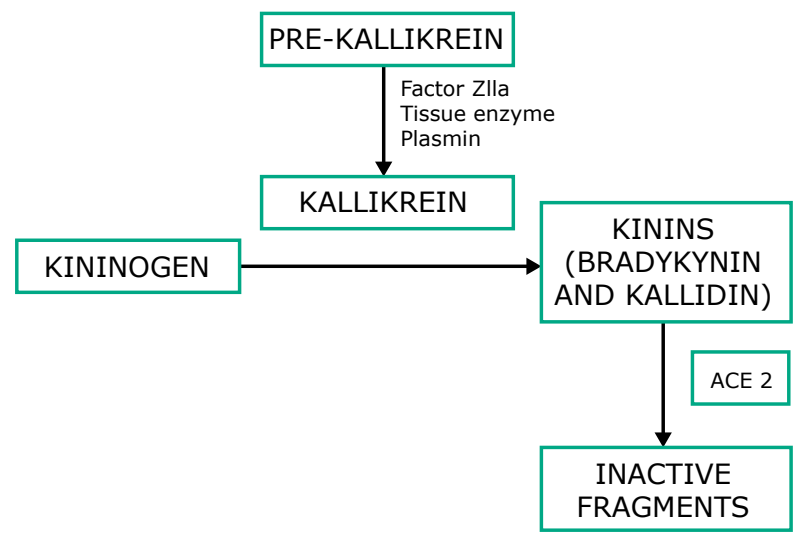

Flowchart 1: The scheme summarizes the KininogenKallikrein-Kinin System and the degradation of kinins by ECA 2 (Angiotensin-Converting Enzyme 2).

Bradykinin is a very potent non-peptide vasoactive, capable of dilating venules through the release of nitric oxide (NO) and increasing vascular permeability through its action on B1 and B2 receptors $^{9}$. The Angiotensin-Converting Enzyme 2 (ACE 2), also known as Kininase II, is one of those responsible for degrading kinins, including bradykinin $^{10,11}$. Sars-CoV-2 binds to ACE 2 receptors to enter the cells ${ }^{1,11}$. Thus, in COVID-19, because this virus is bound to this receptor, there may be an infra-regulation of ACE 2 receptors, which may result in decreased kinin degradation, thus generating a 
cascade that may be partially responsible for the emergence of some of the clinical manifestations of COVID-19, among them, angioedema ${ }^{8}$. Some studies have even indicated the pharmacological blockade of the Kininogen-Kallikrein-Kinin System (KKKS) as a possible therapy to fight the hyperinflammatory state present in COVID-19 ${ }^{11}$.

Endothelial involvement in COVID-19 may also be an explanation for this rare manifestation of angioedema in COVID-19. Histopathological studies have demonstrated that SARS-CoV-2 is responsible for causing severe endothelial damage associated with the intracellular presence of the virus $^{10,13}$. The ACE 2 receptor is widely present in endothelial cells ${ }^{13}$. The action of Sars-CoV-2 could result in endotheliitis, which would lead to platelet overactivation, aggregation, and retention, thereby determining the formation of microthrombi in the damaged site ${ }^{10,12}$. Research has therefore indicated that COVID-19, in addition to possibly developing a Severe Acute Respiratory Syndrome (SARS), may also involve a diffuse, multisystemic endotheliitis ${ }^{1}$.

It is therefore probable that the reported patient developed angioedema because of a decrease in bradykinin metabolism through infra-regulation of the ACE2 receptor upon binding with the virus, and the endothelial lesion of the viral infection in the cells itself, which may have resulted in a change in permeability and, consequently, in the observed angioedema. It may be suggested that this dynamic interaction of the endothelial system with the immune system results in a variety of clinical manifestations observed in COVID-19, including its progression and severity.

This report of angioedema has reinforced the participation of the endothelial and immune systems in the pathophysiology of COVID-19. Understanding these complex mechanisms at a time when many questions are yet to be answered may contribute to a better understanding of the clinical manifestations, and offer important clues on therapeutic targets onto which we should place our attention.

\section{REFERENCES}

1. Li H, Liu L, Zhang D, Xu J, Dai H, Tang N, et al. SARSCoV-2 and viral sepsis: observations and hypotheses. Lancet [Internet]. 2020;395(10235):1517-20. DOI: https://doi.org/10.1016/S0140-6736(20)30920-X
2. Sardu C, Gambardella J, Morelli MB, Wang X, Marfella R, Santulli G. Hypertension, Thrombosis, Kidney Failure, and Diabetes: Is COVID-19 an Endothelial Disease? A Comprehensive Evaluation of Clinical and Basic Evidence. J Clin Med. 2020;9(5):1417. DOI: https://doi. org/10.3390/jcm9051417

3. Rodriguez-Morales AJ, Cardona-Ospina JA, GutiérrezOcampo E, Villamizar-Peña R, Holguin-Rivera $Y$, Escalera-Antezana JP, et al. Clinical, laboratory and imaging features of COVID-19: A systematic review and meta-analysis. Travel Med Infect Dis [Internet]. 2020;34(2020):101623. DOI: https://doi. org/10.1016/j.tmaid.2020.101623

4. De Albuquerque $\mathrm{PL}$, da Silva RB, De Araújo RMS. COVID-19: origem, patogênese, transmissão, aspectos clínicos e atuais estratégias terapêuticas. Rev Prevenção Infecção e Saúde [Internet]. 2020;6(3). DOI: https:// doi.org/10.26694/repis.v6i0.10432 [In Press]

5. Monte LM do, Mendes LA, Camargo RL, Gomes RS de S, Da Silveira PHA, Seyfarth MSC, et al. Complicações atípicas e características clínico-epidemiológicas do COVID-19: uma revisão integrativa. Eletronic J Collection Health. 2020;(46):e3699. DOI: https://doi. org/10.25248/reas.e3699.2020

6. Recalcati S. Cutaneous manifestations in COVID-19: a first perspective. J Eur Acad Dermatol Venereol. 2020;(34):e212-3. DOI: https://doi.org/10.1111/ jdv. 16387

7. Bisinotto FMB, Seabra BC, Lóes FBP, Martins LB, Silveira LAM da. Postoperative angioedema induced by angiotensin-converting enzyme inhibitor: case report. Brazilian J Anesthesiol [Internet]. 2019;69(5):521-6. DOI: https://dx.doi.org/10.1016/j.bjane.2019.09.002

8. Cohen AJ, Difrancesco MF, Solomon SD, Vaduganathan M. Angioedema in COVID-19. Eur Heart J. 2020; ehaa452. DOI: https://doi.org/10.1093/eurheartj/ehaa452

9. Male D, Brostoff J, Roff DB, Roitt IM. Imunologia. 8th ed. São Paulo: Elsevier; 2014. 488

10. Ackermann M, Verleden SE, Kuehnel M, Haverich A, Welte $\mathrm{T}$, Laenger $\mathrm{F}$, et al. Pulmonary Vascular Endothelialitis, Thrombosis, and Angiogenesis in Covid-19. N Engl J Med [Internet]. 2020;383(2):120-8. DOI: https://doi. org/10.1056/NEJMoa2015432

11. Colarusso C, Terlizzi M, Pinto A, Sorrentino R. A lesson from a saboteur: high molecular weight kininogen (HMWK) impact in COVID-19. Br J Pharmacol [Internet]. 2020;1-7. DOI: https://doi.org/10.1111/bph.15154

12. Rapkiewicz AV, Mai $X$, Carsons SE, Pittaluga $S$, Kleiner DE, Berger JS, et al. Megakaryocytes and platelet-fibrin thrombi characterize multi-organ thrombosis at autopsyin COVID-19: A case series. EClinicalMedicine. 2020; 100434. DOI: https://doi.org/10.1016/j. eclinm.2020.100434

13. Varga $Z$, Flammer $A J$, Steiger $P$, Haberecker $M$, Andermatt $R$, Zinkernagel AS, et al. Endothelial cell infection and endotheliitis in COVID-19. Lancet [Internet]. 2020;395(10234):1417-8. DOI: https:// doi.org/10.1016/ S01406736(20)30937-5 